\title{
16. IGNEOUS ROCKS FROM THE CONGLOMERATES OF DEEP SEA DRILLING PROJECT HOLE 445
}

\author{
G. V. Nisterenko, Vernadsky Institute of Geochemistry and Analytical Chemistry, \\ U. S. S. R. Academy of Sciences, Moscow
}

\begin{abstract}
Igneous rocks from the conglomerates of DSDP Hole 445 (Leg 58) are represented by dolerites and basalts having plagioclases of andesine composition. According to their bulk chemistry, they are alkaline and high-alumina basic rocks. Comparison of chemical and mineral compositions permits their tentative classification as mugearite-hawaiite. The high-alumina composition of the basalts can be used as petrochemical evidence that the Daito Ridge was once part of an ancient (now submerged) island arc.
\end{abstract}

\section{INTRODUCTION}

Igneous rocks occurred as pebbles in conglomerates within a sequence of middle-Eocene sedimentary rocks at sub-bottom depths of 645 to 892 meters (Sections 69-2, 71-1, 74-1, 74-3, 83-4, 93-1, 93-2, 94-5) in Hole 445. Their presence is due to transportation as pebbles from coastal islands down to significant depths by the processes of debris flow, fluidized flow, and slumping-sliding (Site 445 report, this volume).

The coarsest pebble conglomerates (some pebbles reach $6 \mathrm{~cm}$ in diameter) were found near the bottom of the hole (Sections 93-1, 93-2, 94-5). It was possible to sample the pebbles for petrographic and chemical study.

\section{BRIEF PETROGRAPHIC DESCRIPTION}

\section{Sample 445-93-2, 96-99 cm}

Fine grained dolerite with microdiabasic texture. Rare phenocrysts of plagioclase (as large as $3 \mathrm{~mm}$ ). Composition: plagioclase 50 per cent, pyroxene $35-40$ per cent, opaque minerals 7 per cent. Rock is slightly altered.

\section{Sample 445-93-1, 140-144 cm}

Medium-grained dolerite with ophitic texture. Composition: plagioclase $\left(\mathrm{An}_{37}\right) 55$ per cent (as large as 3$4 \mathrm{~mm}$ ), clinopyroxene $35-40$ per cent opaque minerals (up to $0.5 \mathrm{~mm}$ ). Rock is slightly altered.

\section{Sample 445-93-1, 96-100 cm}

A phyric basalt with fine-grained, intersertal texture. Several phenocrysts of untwinned feldspar (up to $0.5 \mathrm{~mm}$ ) and a single grain of clinopyroxene. Composition: plagioclase, altered glass, small grains of magnetite $(10 \%)$. Rock is moderately altered.

\section{Sample 445-94-5, 52-54 cm}

-Plagioclase phyric basalt, fine grained. The texture intersertal to intergranular. Plagioclase phenocrysts com- prise 10 to 15 per cent of the rock. Matrix is composed of short prismatic crystals of feldspar in altered glass. Some patches are composed of palagonitized glass $(20 \%)$. Rock is moderately altered.

Sample 445-93-1, 77-83 cm

Plagioclase phyric basalt. Texture intersertal. Fifty per cent of the rock is composed of plagioclase $\left(\mathrm{An}_{30}\right)$, mostly 0.5 to $1 \mathrm{~mm}$, but as large as $3 \mathrm{~mm}$ within an altered-glass matrix. Opaque minerals 3 per cent. Rock is highly altered.

\section{Sample 445-93-2, 24-26 cm}

Highly altered basalt (probably plagioclase phyric basalt) with plagioclase relics replaced by epidote.

Samples 445-94-5, 70-72 cm and 445-94-5, 106-109 cm have not been studied in thin sections and are characterized by chemical analyses only.

All rocks are altered by secondary processes, but to different degrees. Glass is replaced by palagonite with minor chlorite. Plagioclase is replaced by epidote. Albitization is absent. Rare vesicles are filled with calcite. Alteration increases in the order of listing in Table 1, from slightly altered dolerite of Sample 445-93-2, 96$99 \mathrm{~cm}$ (analysis 1) to basalt of Sample 445-93-2, 24$26 \mathrm{~cm}$ (analysis 8 ) which is intensely replaced by secondary minerals.

Thus, igneous rocks from the conglomerates of Hole 445 represent basalts and dolerites of distinct compositions. They resemble each other, yet, they differ sharply from basalts of all other holes of Leg 58 by the presence of more-sodic plagioclase $\left(\mathrm{An}_{30-37}\right)$. This feature is in accord with the chemical composition of the rocks.

\section{CHEMICAL COMPOSITION}

According to petrographic characteristics, analyses 1 through 5 in Table 1 represent slightly altered rocks, and analyses 6 through 8 represent intensely altered basalts. This is expressed by the $\mathrm{CO}_{2}$ and $\mathrm{H}_{2} \mathrm{O}^{+}$distribution. The concentrations of these components are generally 
TABLE 1

Chemical Composition and Norms of Igneous Rocks from Conglomerates of Hole 445

\begin{tabular}{|c|c|c|c|c|c|c|c|c|c|c|c|c|c|c|c|c|}
\hline $\begin{array}{c}\text { Sample } \\
\text { (interval in } \mathrm{cm} \text { ) }\end{array}$ & $\begin{array}{l}\text { Analysis } \\
\text { No. }\end{array}$ & $\mathrm{SiO}_{2}$ & $\mathrm{TiO}_{2}$ & $\mathrm{Al}_{2} \mathrm{O}_{3}$ & $\mathrm{Fe}_{2} \mathrm{O}_{3}$ & $\mathrm{FeO}$ & $\mathrm{MnO}$ & $\mathrm{MgO}$ & $\mathrm{CaO}$ & $\mathrm{Na}_{2} \mathrm{O}$ & $\mathrm{K}_{2} \mathrm{O}$ & $\mathrm{P}_{2} \mathrm{O}_{5}$ & $\mathrm{CO}_{2}$ & $\mathrm{H}_{2} \mathrm{O}^{+}$ & $\mathrm{H}_{2} \mathrm{O}^{-}$ & Total \\
\hline $445-93-2,24-26$ & 8 & 51.00 & 1.06 & 18.50 & 7.93 & 2.26 & 0.13 & 3.03 & 3.80 & 4.07 & 3.06 & 0.100 & 0.97 & 4.40 & 0.37 & 100.16 \\
\hline $445-93-1,77-83$ & 7 & 50.20 & 1.00 & 18.25 & 6.71 & 2.55 & 0.22 & 4.74 & 5.20 & 4.84 & 1.72 & 0.136 & 0.80 & 3.27 & 0.54 & 100.08 \\
\hline $445-94-5,52-54$ & 6 & 49.80 & 0.95 & 17.70 & 6.30 & 3.79 & 0.18 & 4.62 & 3.75 & 5.52 & 1.13 & - & 0.54 & 3.84 & 2.64 & 99.70 \\
\hline $445-93-1,96-100$ & 5 & 48.60 & 1.04 & 17.50 & 8.12 & 3.13 & 0.16 & 5.26 & 7.57 & 3.85 & 1.47 & 0.187 & 0.43 & 1.49 & 1.66 & 100.47 \\
\hline $445-94-5,70-72$ & 4 & 49.00 & 1.10 & 17.80 & 7.40 & 3.92 & 0.19 & 4.50 & 4.50 & 4.29 & 1.90 & 0.098 & 0.36 & 2.17 & 2.51 & 99.69 \\
\hline $445-93-1,140-144$ & 3 & 47.40 & 0.77 & 19.15 & 8.97 & 2.81 & 0.19 & 4.11 & 6.62 & 4.78 & 0.86 & 0.137 & 0.16 & 2.67 & 1.21 & 100.04 \\
\hline $445-94-5,106-109$ & 2 & 51.40 & 0.83 & 15.50 & 4.35 & 4.19 & 0.18 & 5.42 & 6.35 & 3.80 & 1.46 & 0.105 & 0.15 & 2.77 & 2.71 & 99.32 \\
\hline $445-93-2,96-99$ & 1 & 49.30 & 0.88 & 13.00 & 5.77 & 5.62 & 0.20 & 7.95 & 9.00 & 2.78 & 1.25 & 0.098 & 0.14 & 2.21 & 1.14 & 99.36 \\
\hline $\begin{array}{c}\text { Sample } \\
\text { (interval in } \mathrm{cm} \text { ) }\end{array}$ & $\begin{array}{l}\text { Analysis } \\
\text { No. }\end{array}$ & Q & Or & $\mathrm{Ab}$ & $\mathrm{Ne}$ & An & $\mathrm{Di}$ & Hy & O1 & $\mathrm{Ilm}$ & Mt & Hem & Ap & & & \\
\hline $445-93-2,24-26$ & 8 & 3.41 & 19.05 & 36.27 & - & 19.17 & - & 7.95 & - & 2.13 & 4.85 & 5.00 & 0.25 & & & \\
\hline $445-93-1,77-83$ & 7 & - & 10.68 & 39.81 & - & 25.36 & 0.33 & 11.60 & 0.49 & 1.99 & 6.33 & 2.68 & 0.34 & & & \\
\hline $445-94-5,52-54$ & 6 & - & 7.12 & 49.82 & - & 19.85 & - & 6.40 & 4.52 & 1.92 & 9.75 & - & - & & & \\
\hline $445-93-1,96-100$ & 5 & - & 8.97 & 33.62 & - & 26.98 & 8.19 & 7.14 & 1.81 & 2.04 & 7.83 & 2.98 & 0.46 & & & \\
\hline $445-94-5,70-72$ & 4 & 0.74 & 11.86 & 38.33 & - & 22.90 & - & 11.83 & - & 2.21 & 10.61 & 0.50 & 0.24 & & & \\
\hline $445-93-1,140-144$ & 3 & - & 5.31 & 41.86 & 0.19 & 29.51 & 2.98 & - & 6.52 & 1.53 & 7.76 & 4.01 & 0.34 & & & \\
\hline $445-94-5,106-109$ & 2 & 3.28 & 9.22 & 34.35 & - & 22.37 & 8.40 & 13.70 & - & 1.68 & 6.74 & - & 0.27 & & & \\
\hline $445-93-2,96-99$ & 1 & 0.83 & 7.71 & 24.54 & - & 20.15 & 20.49 & 15.58 & - & 1.74 & 8.83 & - & 0.24 & & & \\
\hline
\end{tabular}

high in altered basalts (analyses 6-8). Taking this into account, one can infer that the first five samples should nearly reflect the primary composition of these igneous rocks.

Table 1 shows that all these basalts and dolerites have high contents of alkalies (more than $4 \%$ ) and alumina (more than $17 \%$, excluding analyses 1 and 2). These rocks lie in the field of alkali basalts, not only in the well-known diagram of alkalies versus silica (Irvine and Baragar, 1971), but also in Kuno's diagram of alkalies versus alumina (Kuno, 1960). However, according to normative composition the basalts are related to tholeiites. Only one sample (analysis 3 ) having a small amount of normative nepheline $(0.19 \%)$, lies at the boundary of alkaline olivine basalts. Even in the extreme case of recalcalation on the assumption that all iron is ferrous, olivine also appears (at the expense of magnetite), and nepheline $(2-5 \%)$ appears only in those rocks which have no normative quartz (analyses $3,5,6,7$ ).

In reality, all the basalts are probably in the olivine-hypersthene-diopside field, partly extending to the alkaline field, but near the boundary of critical undersaturation (analyses 3, 5, 6, 7). Comparison of their chemical and mineral $\left(\mathrm{An}_{30-37}\right)$ compositions permits their tentative classification as members of the mugearite-hawaiite series (MacDonald, 1960).

The high alumina content of the igneous rocks from the conglomerates of Hole 445, which is typical of basalts of the rear parts of the island arcs (Kuno, 1966), can be regarded as petrochemical evidence that Daito Ridge is an ancient, relict island arc now submerged to a significant depth.

\section{REFERENCES}

Irvine, T. N., and Baragar, W. R. A., 1971. A guide to the chemical classification of the common volcanic rocks. Can. J. Earth Sci., 8, 523-548.

Kuno, H., 1960. High-alumina basalt. J. Petrol., 1, 121-145. , 1966. Lateral variation of basalt magma-type across continental margins and island arc. Bull. Volcanol., 29, 195-222.

MacDonald, G. A., 1960. Dissimilarity between continental and oceanic rock types. J. Petrol., 1, 172. 